\title{
Influence of Physical Facilities on Meeting Expectation for Transition from Preschool to Grade one in Elgeyo Marakwet County, Kenya
}

Cherop Salina Jepkemoi, Esther Bitok, Moses Kapkiai

To Link this Article: http://dx.doi.org/10.6007/IJARBSS/v12-i1/12205

DOI:10.6007/IJARBSS/v12-i1/12205

Received: 20 November 2021, Revised: 24 December 2021, Accepted: 01 January 2022

Published Online: 28 January 2022

In-Text Citation: (Jepkemoi et al., 2022)

To Cite this Article: Jepkemoi, C. S., Bitok, E., \& Kapkiai, M. (2022). Influence of Physical Facilities on Meeting Expectation for Transition from Preschool to Grade one in Elgeyo Marakwet County, Kenya. International Journal of Academic Research in Business and Social Sciences, 12(1), 1621- 1635.

\section{Copyright: @ 2022 The Author(s)}

Published by Human Resource Management Academic Research Society (www.hrmars.com) This article is published under the Creative Commons Attribution (CC BY 4.0) license. Anyone may reproduce, distribute, translate and create derivative works of this article (for both commercial and non0-commercial purposes), subject to full attribution to the original publication and authors. The full terms of this license may be seen

at: http://creativecommons.org/licences/by/4.0/legalcode

$$
\text { Vol. 12, No. 1, 2022, Pg. } 1621-1635
$$




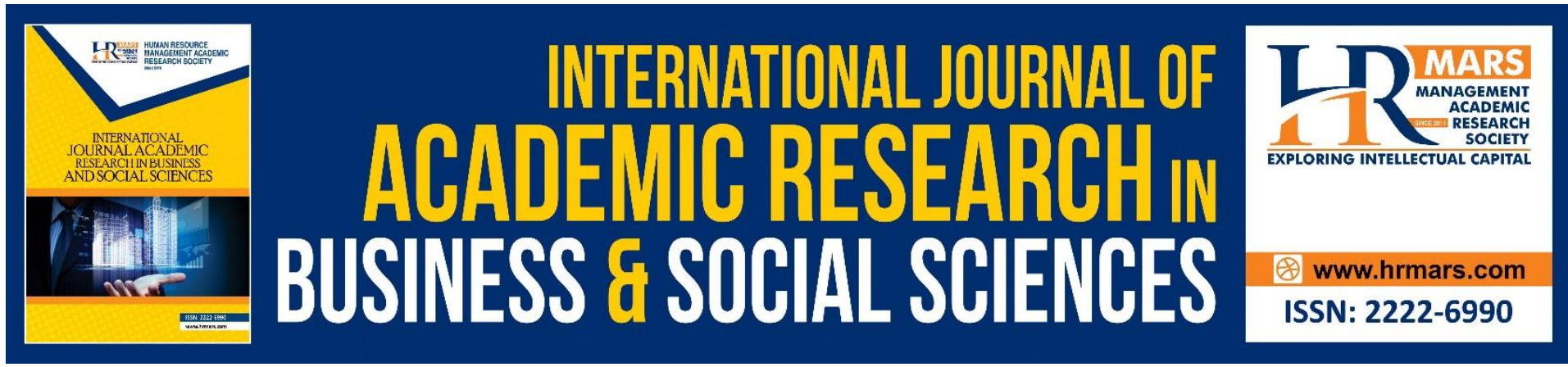

\title{
Influence of Physical Facilities on Meeting Expectation for Transition from Preschool to Grade one in Elgeyo Marakwet County, Kenya
}

\author{
${ }^{1}$ Cherop Salina Jepkemoi, ${ }^{2}$ Dr. Esther Bitok, ${ }^{3}$ Dr. Moses \\ Kapkiai
}

${ }^{1}$ Doctor of Philosophy Degree in Early Childhood Development Education, ${ }^{2}$ Lecturer, Department of Early Childhood Development Education Kisii University Kisii University, Kisii, Kenya, ${ }^{3}$ Lecturer, Department of planning and management, Kisii University, Kisii, Kenya

Email: estherbitok@kisiiuniversity.ac.ke, moseskapkiai@kisiiuniversity.ac.ke

\begin{abstract}
In order to increase the transition from preprimary to primary, appropriate expectation measures must be set. However, Grade 1 teachers complain about a pre-school student's bad entry behavior. The following objective drove the study to find out the influence of physical facilities in meeting expectations for the transition from preschool to Grade one. The study was based on the constructivist theory of learning. This study employed a survey research design. The study target was 462 Preschools attached to public primary schools in Elgeyo Marakwet. The target population was 1848 participants comprising 462 headteachers, 924 preschool teachers and 462 Grade one teachers. The sample size of the study was 214 schools, 272 preschool and 210 Grade one teachers. The study employed stratified random and simple random sampling. Research instruments used in this study were questionnaires and interview schedules. A pilot study was carried out in 10 randomly selected schools in Uasin Gishu County to ascertain the reliability and validity of research instruments. Qualitative data collected using interviews were analyzed using content analysis. Quantitative data were coded, cleaned and analyzed using Statistical Package for Social Science (SPSS version 26) to generate descriptive and inferential statistics. Descriptive statistics used were frequency, percentage, mean and standard deviation. Inferential statistics used were correlation and multiple regression. Analyzed data were presented using tables and reports. Regression of coefficients results shows that physical facilities have a negative and significant effect on meeting expectations for the transition from preschool to Grade one in Elgeyo Marakwet county $\left(\beta_{1}=-\right.$ $0.140, p=0.037)$. The study concluded that physical facilities have a significant negative influence on meeting expectations for the transition from preschool to Grade one. The study recommends the county government and other preschools centers stakeholders to ensure that they build and avail the physical facilities.
\end{abstract}

Keywords: Physical Facilities, Transition, Meeting Expectation, Grade One, Influence, Influence 


\section{Introduction}

Education is a series of actions which entail obtaining and imparting of knowledge, adeptness and values that societies need and employ. This is perceived globally as critical in the development of human beings and for the most part as a fundamental human right (Struthers, 2015). According to the Global Campaign for education Report of 2007, those devoted to universal education agreed that education is a significant fragment of the solution for majority of the world's development issues. Education is perceived as a necessity for economic expansion and poverty reduction. The knowledge and decision-making expertise acquired in schools enhances family health and prosperity.

Transition is a set of action that result to change that learners experience when they move from one level of learning to the next. The measures support a learner to develop positive attitude and impressions concerning school and learning (Hacieminoglu, 2016). The widely and enabling factors to enable transition are accessibility of multiplicity and variety of services provided by the concerned persons surrounding the learner. These are parental contribution, peer group undertakings, home support, family participation, parent - teacher partnership and the care given by the Pre-School education-based Centre (Winder \& Corter, 2016). On the same hand, preschool education connected services and social economic factors are also essential for they determine entry behavior and age of the learner (Halle et al., 2014).

In countries in Asia and pacific region, there is no consolidated policy to finance Pre-School programs (Nirmola \& Jin, 2017). In the education sector, financing preferences are for primary schools, with Pre-School and transitional programs being overlooked. Typically, in majority of the countries in the regions, consolidated plan of actions for funding and management of PreSchool care and education programs are non-existent. Better access to information on financing is within easy reach for primary education while such information is not obtainable for pre-primary education in countries that have placed prime concern to developing and scaling up pre-primary opportunities in the public sector (Birchler \& Michaelowa, 2016).

Transition is the shift from education to education. The skills-based curriculum (CBC) is 100 percent in education from preschool to high school in Kenya and Elgeyo Marakwet. Preschool is an important or initial level of education that must be studied to achieve an effective transition to first grade. Learners should exceed expectations and meet expectations in order to move to the first level. However, most learners transit when they have not met expectations for transition. This level determines the transition of other levels of education as the learners climb up the ladder.

Parents, peers, home-based support and parent-teacher partnership must be included in the transition. Transition from one cognitive stage to one another can be experienced in terms of learning environment, location, pre-school teachers, curriculum. At present, the digital age has been mainly based on letter names, identification and writing procedures for the transition from preprimary to grade one. These have frustrated students, especially those who are older and not in the first grade, in many years. Since the devolution of Pre-School to the County Government in Kenya, and the Competency Based Curriculum (CBC) implementation there has been different expectation to enhance transition from Pre-School to Grade one.

The move from pre-primary to first grade needs to set proper expectations for an efficient transition and for fear of discontinuities to be easier. At this stage teachers in grades 1 complain about the poor entry behavior of pupils in grades one. The researcher found, however, that no specific study was conducted on anticipatory factors that affect the transition of the learner from pre-school, in particular with respect to the implementation of 
a $C B C$ curriculum. It was then for this reason that the researcher felt the need to address the gap by investigating on influence of physical facilities on meeting expectation for transition from preschool to Grade one in Elgeyo Marakwet county, Kenya.

\section{Theoretical Framework}

The study was guided by constructivist theory developed by Jean Piaget in 1950 . The theory communicates technique through which knowledge is itemized by learners. The theory suggested that via processes of understanding and iassimilation ilearners igain inew iknowledge ifrom itheir iencounters. iWhen ilearners iassimilate, ithey iconsolidate the inew iexperiences iinto ian iexisting iframework iwithout modifying the framework. The theory of Jean Piaget suggests the construction of knowledge out of the Pre-School teaching method as a factor to enhance transition (Mooney, 2013). The theory enhances uniform teaching experiences in this level of Pre-School and generate the knowledge expectation for effective transition ifrom ipre-school ito iGrade ione. The theory support and guide the study by PreSchool teachers accommodating and assimilating factors with an aim to enhance expectations for transition ifrom iPre-school ito iGrade ione.

However, constructivism is often linked with pedagogic techniques that advances active learning by creating Pre-School factors of transition used by pre - school teachers for a common goal. All learners have unique needs and background and is seen by constructivists as also unique multidirectional individual (Kiraly, 2014). Teaching method is a drastic alteration of role which means that a teacher needs to exhibit a totally different set of skills used in instruction and enhance expectation for transition (Rhodes \& Bellamy, 2012). Teachers ought to adopt the learning experience by taking the initiative to steer the total experience towards where learners desire to create value including factors of transition.

The learning facilities in this case, the classes should also support the learners' environmental conduciveness for learning (Divesta, 2017). The critical role is to support the learner in becoming an effective thinker. Constructivist learners view learning as where learners would be evaluated on strands or sub strands in order to discover principal concepts and facts for themselves (Amineh \& Asl, 2015). A teacher of constructivism would have, a curriculum structured just enough to make sure that the learning gets clear guidance and parameters within which to achieve the learning objectives (Slavin, 2019).

Pritchard (2017) argues that learners should be cognitively active during learning and that teachers should use guided factors to make them learn and get traced from one level of education to the next. Factors of transition are supported by this theory because learning should have a sequence of structures to be learned before transition. Provision of basic needs help learners to learn tirelessly and achieve requirements for the Pre-school, the adequacy and size of physical facilities are key factors influencing expectation for effective transition of learners from pre-school to Grade one.

\section{Empirical Review}

\section{Physical Facilities on Meeting Expectation for Effective Transition from Pre-School to Grade one}

According to Alimi, Ehinola and Alabi (2012), Physical Facilities refers to the entire school plant such as blocks of classrooms, staff rooms, laboratories, workshops, libraries, laboratory equipment. Yolanda and Suryana (2020) viewed Physical Facilitiess like buildings, grounds, furniture and apparatus along with types of equipment essential for imparting, implementing and managing ECE. Physical Facilities is a formal institution that serves children aged between 
four to six years, thus, enhances their development through fun learning activities (Yolanda \& Suryana, 2020).

Physical Facilities $s$ in a school system are important because it protects children and teachers' well-being such as comfort, safety and performance while at school (Alimi, 2012). A number of scholars have noted the importance of Physical Facilities in the development and improvement of ECE programmed (Vandenbroeck \& Lenaerts, 2018; Barret et al., 2018). According to Vandenbroeck and Lenaerts (2018), the development of ECE facilities for young children in Europe promotes sustainable and inclusive growth in children, resulting in high participation rates in ECE institutions. Barret et al (2018) noted that school physical facilities where children have rotational use of classes such as science laboratories, art workshops, library, and sports fields enhance participation rates. Hence, physical facilities alleviates overcrowding situations in some schools due to the intensive use of classes.

Barret et al (2018) further observed that when spaces permit flexible arrangement of furniture and equipment especially in ECE institutions, children are able to acquire collaboration, teamwork and other interpersonal skills which enhance their participation rates. Where there is fair distribution of adequate ECE facilities, every member of each age group can attend a school that results to high participation rates (Barret et al., 2018). Despite the study focusing on adequacy of ECE facilities, there is still a research gap on availability, number and status of Physical Facilities $s$ in ECE and how they influence participation rates in ECE children.

Borgman, Scharnhorst and Golshan (2018) noted that outdoor play activity positively impacts on children's social, emotional, and cognitive development. However, physically strenuous play contributes to healthy brain development which enhances learning and improves memory. When children are engaged in outdoor play; they become flexible, increase selfawareness, happiness, stress, and aggression reduces (Borgman et al., 2018). Borgman et al (2018) concluded that children with higher fitness levels consistently show better academic performance, particularly in mathematics and reading. Hence, an ECE institution without outdoor play Physical Facilities such as a playground can significantly inhibit children's participation rates, which can hinder the achievement of goals and objectives. Similarly, like was the case with Borgman et al (2018) study, the current study explored the availability and status of physical facilities which are important in promoting participation rates among children.

Higgins (2017) observed that in South America (Latin America) established that unavailability of physical facilities conducive for learning show lower test scores and high-grade repetition disrupting effective transition. Research results have shown that less quality has quantity that create a big challenge of teaching and learning activities that in turn have a adverse effect on the improvement and transition in Pre-School (Olaleye, 2012).

The enhancement of the learning activities is achieved by making certain learners access the best education as per the national objectives of education. The importance of Pre-School development is not fast setting the foundation for cognitive, social, emotional, physical and language development of learners, but often is crucial in terms of pinpointing impediments of quality learning. To acquire quality education learning environment is also a determining factor (UN, 2015). Quality environment is defined by accessibility of facilities infrastructure and resources.

In Zimbabwe physical facilities for learning and materials of ICT programmed are in state of despair, thus, has stagnated the implementation of education and effective transition of preschool levels to Grade one (Chekwesis, 2015). Sanitary and hand washing provisions are 
very essential for well-being of learners because good hand washing minimizes the chances of transmission of diseases and infections thus creating an environment which facilitates good learning and effective transition to another level. It is recommended that besides the ratio of 1:20 of toilets to pupils, all Pre-School Center should have at least one (1) toilet for over 10 teachers. These provisions are very essential for they allow the school to function efficiently and therefore transit effectively (Sitati, 2016).

Pre-School development and education is a basic need on which education for all and majorly foundational education should be based on (Nyamwange, 2012). Pre-School Development and Education is provided to learners prior to the age of commencing Grade one education at the age of six (6) years (Obiweluozor, 2017). Pre-School Education can advance constructive developmental encounters and autonomy while also maximizing learning and development potential. The goal of Pre-School education is to issue development support and care for learners in their early years so that they can gain the skills essential for future learning and academic achievements in school (Agbenyega \& Klibhong, 2015).

Thus, quality education is still a primary factor towards learners acquiring skills related to reading, writing and even speaking (Okebukola, 2019). Satar (2013) perceived quality and appropriateness of resources accessible to education and that quality is the footwork of educational establishments that can be rated on scale of reference. Henard and Roseveare (2012) were of the opinion that quality education is ascertained by the input such as the guiding policies instructional materials, learning duration curriculum content, school culture, costs and, quality assurance, teacher pupil ratio, and above all the teachers and management responsibilities. However, research studies have established that preschool learners are learning outside due to inadequate physical facilities (Mabatuk, 2016). Pre-school classrooms often fall short of minimum education standard like many of them learn in semi-permanent building (Jepleting, 2019). All these slows the transition rate of learners from Pre-School to Grade one.

\section{Conceptual Framework}

The conceptual framework is on the factors influencing preschool learners in Kenya to enhance expectation for effective transition from Pre-School to Grade one.

Independent Variables

\section{Dependent Variable}

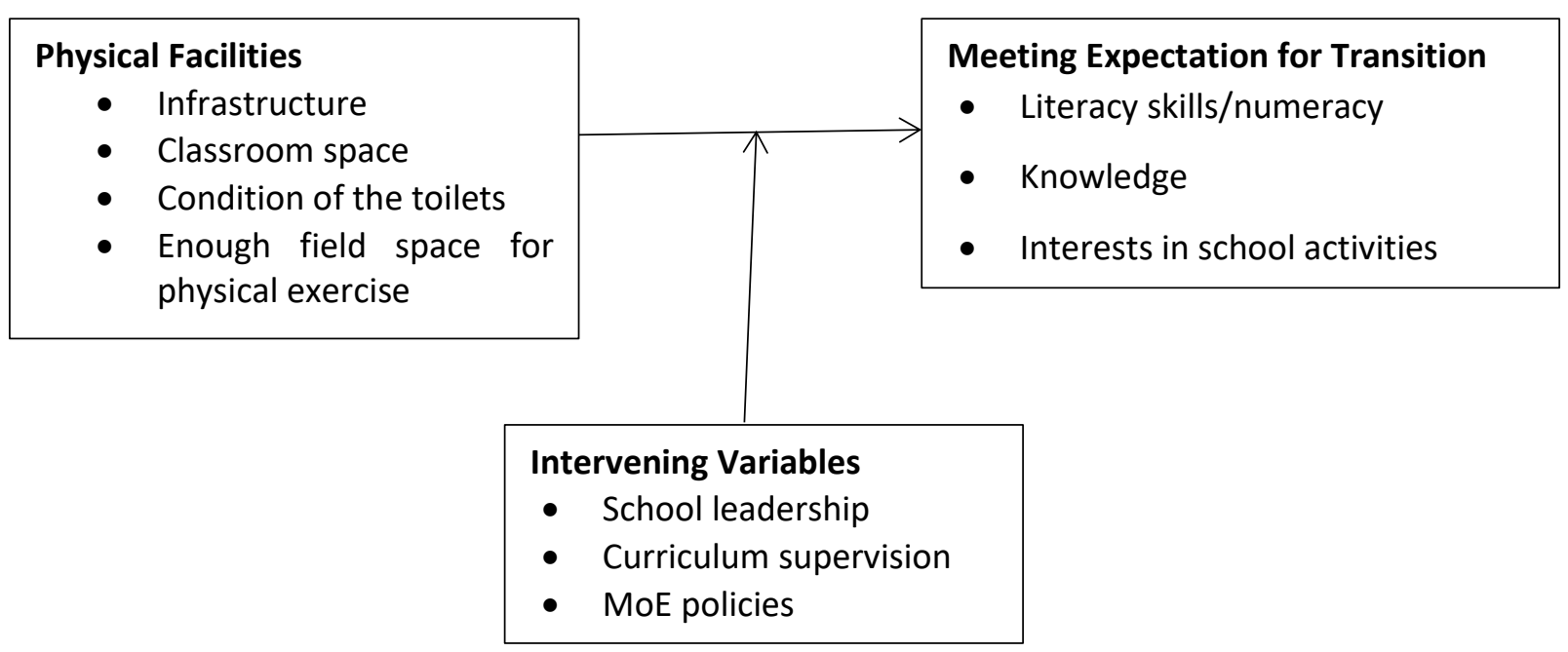

Figure 1 Conceptual Framework

Source: Author (2021) 


\section{Research Methodology}

This study used survey research design. The survey research is quick and involves descriptive events experienced by individuals or a group of individuals in a research study and making inference of the problem using the sample population. The study targeted 462 Pre-Schools attached to public primary school in Elgeyo Marakwet. From these 462 schools the study targeted 462 headteachers, 924 preschool teachers and 462 Grade one teacher.

The sample size of 214 schools were obtained using Yamane formula $(n=N / 1+N e 2)$. The study used stratified sampling to select the four sub counties in Elgeyo Marakwet (Keiyo South, Keiyo North, Marakwet West, Marakwet East), from each sub-county the researcher selected 5 zones which formed 20 stratus. From each strata the researcher used purposive sampling to select 20 headteachers to participate in the study. Further, the study used purposive sampling to select 20 preschool teachers from schools which headteachers were selected to participate in interviews. Furthermore, simple random sampling was used to select preschool and Grade one teachers to participate in questionnaires. Sample size 272 preschool teachers, 210 Grade one teacher were obtained using Krejcie and Morgan, formula for finite population. Therefore, the sample size were 272 preschool teachers, 210 Grade one teacher, 20 headteachers and 20 preschool teachers.

The research produced both qualitative data and quantitative data. Qualitative data collected using interviews were analyzed using thematic method analysis. Quantitave idata were coded, icleaned iand iassessed iusing iStatistical iPackage for Social iScience i(SPSS iversion i26) ito igenerate idescriptive istatistics. The frequency distributions, and percentages all of which are descriptive statistics were employed to analyze key assessment variables and measures of central tendencies such as means and standard deviation. Regression model was used to estimate the causal relationships between beta and other chosen variables as indicated below;

\section{$\mathbf{Y}=\boldsymbol{\beta}_{0}+\boldsymbol{\beta}_{1} \mathbf{x}_{1}+\boldsymbol{\varepsilon}$}

Where:

$\mathrm{x}=$ the independent variables -

$\mathrm{x}_{1}=$ physical facilities

$\mathrm{Y}=$ the dependent variable (meeting expectation for effective transition from preschool to Grade one)

$\beta$ - Beta

$\varepsilon$ - Error Term. The analyzed data were then presented in form of tables and prose for interpretation, summary, conclusions and recommendations.

\section{Research Findings and Discussions \\ Response Rate}

There were 272 pre-school teachers and 210 grade one teacher. Those who filled and returned questionnaires were 226 respondents making a response rate of $83.1 \%$ for preschool teachers and 192 respondents making a response rate of $91.4 \%$ for pre-school teachers.

\section{Influence of Physical Facilities on Meeting Expectation for Transition from Preschool to Grade one in Elgeyo Marakwet County}

The respondents were requested to indicate their level of agreement on various statements relating to the influence of physical facilities on meeting expectation for transition from preschool to Grade one in Elgeyo Marakwet County. A 5-point Likert scale was used where SD 
symbolized strongly disagreed, D symbolized disagreed, UD symbolized undecided, A symbolized agreed and SA symbolized strongly agreed. The results were as presented in Table 1

Table 1 Influence of Physical Facilities on Meeting Expectation for Transition from Preschool to Grade one in Elgeyo Marakwet County

\begin{tabular}{|c|c|c|c|c|c|c|c|c|}
\hline Statements & & SA & A & UD & D & SD & Mean & Sd \\
\hline $\begin{array}{l}\text { 1. The school has permanent } \\
\text { buildings for classes which are } \\
\text { spacious and conducive for } \\
\text { learning }\end{array}$ & $\begin{array}{l}\mathrm{F} \\
\%\end{array}$ & $\begin{array}{l}11 \\
4.8\end{array}$ & $\begin{array}{l}13 \\
5.8\end{array}$ & $\begin{array}{l}7 \\
2.9\end{array}$ & $\begin{array}{l}61 \\
27\end{array}$ & $\begin{array}{l}134 \\
59.5\end{array}$ & 1.72 & 1.009 \\
\hline $\begin{array}{l}\text { 2. Some schools use Mud houses } \\
\text { as classes thatched with grass }\end{array}$ & $\begin{array}{l}F \\
\%\end{array}$ & $\begin{array}{l}20 \\
8.7\end{array}$ & $\begin{array}{l}37 \\
16.3\end{array}$ & $\begin{array}{l}13 \\
5.8\end{array}$ & $\begin{array}{l}67 \\
29.8\end{array}$ & $\begin{array}{l}89 \\
39.4\end{array}$ & 2.26 & 1.356 \\
\hline $\begin{array}{l}\text { 3. Modern built latrines \& toilets } \\
\text { have been constructed in the } \\
\text { schools }\end{array}$ & $\begin{array}{l}\mathrm{F} \\
\%\end{array}$ & $\begin{array}{l}31 \\
13.5\end{array}$ & $\begin{array}{l}22 \\
9.6\end{array}$ & $\begin{array}{l}9 \\
3.8\end{array}$ & $\begin{array}{l}20 \\
8.7\end{array}$ & $\begin{array}{l}146 \\
64.4\end{array}$ & 2.02 & 1.132 \\
\hline $\begin{array}{l}\text { 4. Food store in the school is in } \\
\text { good condition }\end{array}$ & $\begin{array}{l}F \\
\%\end{array}$ & $\begin{array}{l}41 \\
18.3\end{array}$ & $\begin{array}{l}46 \\
20.2\end{array}$ & $\begin{array}{l}11 \\
4.8\end{array}$ & $\begin{array}{l}39 \\
17.3\end{array}$ & $\begin{array}{l}89 \\
39.4\end{array}$ & 2.61 & 1.439 \\
\hline $\begin{array}{l}\text { 5. The school has structured and } \\
\text { spacious fields }\end{array}$ & $\begin{array}{l}\mathrm{F} \\
\%\end{array}$ & $\begin{array}{l}15 \\
6.8\end{array}$ & $\begin{array}{l}26 \\
11.5\end{array}$ & $\begin{array}{l}11 \\
4.8\end{array}$ & $\begin{array}{l}39 \\
17.3\end{array}$ & $\begin{array}{l}135 \\
59.6\end{array}$ & 1.88 & 1.316 \\
\hline $\begin{array}{l}\text { 6. In our school we have Self- } \\
\text { contained administration } \\
\text { block and offices for teachers }\end{array}$ & $\begin{array}{l}\mathrm{F} \\
\%\end{array}$ & $\begin{array}{l}20 \\
8.7\end{array}$ & $\begin{array}{l}48 \\
21.2\end{array}$ & $\begin{array}{l}2 \\
0.9\end{array}$ & $\begin{array}{l}85 \\
37.5\end{array}$ & $\begin{array}{l}72 \\
31.7\end{array}$ & 2.39 & 1.352 \\
\hline $\begin{array}{l}\text { 7. Computer labs available for } \\
\text { digital learning in our school }\end{array}$ & $\begin{array}{l}\mathrm{F} \\
\%\end{array}$ & $\begin{array}{l}15 \\
6.7\end{array}$ & $\begin{array}{l}54 \\
24\end{array}$ & $\begin{array}{l}7 \\
2.9\end{array}$ & $\begin{array}{l}70 \\
30.8\end{array}$ & $\begin{array}{l}80 \\
35.6\end{array}$ & 2.35 & 1.357 \\
\hline $\begin{array}{l}\text { 8. The school mostly have Semi- } \\
\text { permanent buildings for pre- } \\
\text { school learners }\end{array}$ & $\begin{array}{l}\mathrm{F} \\
\%\end{array}$ & $\begin{array}{l}35 \\
15.4\end{array}$ & $\begin{array}{l}46 \\
20.2\end{array}$ & $\begin{array}{l}7 \\
2.9\end{array}$ & $\begin{array}{l}98 \\
43.2\end{array}$ & $\begin{array}{l}41 \\
18.3\end{array}$ & 2.73 & 1.384 \\
\hline 9. In the school, pre-school & $\mathrm{F}$ & 57 & 120 & 9 & 17 & 24 & 3.76 & 1.302 \\
\hline $\begin{array}{l}\text { 10. Learners learn in the open air } \\
\text { due to shortage of classes }\end{array}$ & $\%$ & 25 & 52.9 & 3.8 & 7.7 & 10.6 & & \\
\hline Total number of respondents ( $\mathrm{n}$ ) & 226 & & & & & & 2.41 & \\
\hline
\end{tabular}

Table 1 shows that $11(4.8 \%)$ of the respondents strongly agreed, 13(5.8\%) agreed, $7(2.9 \%)$ were undecided, $61(27 \%)$ disagreed and $134(59.5 \%)$ strongly disagreed with the statement that the school has permanent buildings for classes which are spacious and conducive for learning. Further the study findings showed in terms of means and standard deviation that the respondents agreed the school has permanent buildings for classes which are spacious and conducive for learning (Mean, $=1.72$, Standard Deviation=1.009). The study results agreed with Li and Chen, (2017) who established that availability of spacious and conducive learning materials boosts transition also; kindergarten teachers have a distinct way of consolidating constructivist concepts of development and learning from the national preschool curriculum with their own traditional conventions, while the curriculum put stress 
on free choice practices in kindergartens. Further, Barret et al (2018) argued that unequal distribution of physical facilities such as permanent classroom could create frustration and resentment, resulting in low transition rates in schools.

However, Sando's (2019) showed a positive relationship association between children's transition rate and physical facilities such as classroom. Sando (2019) further argued that having an indoor room for a physical facility in schools may be considered important for children's well-being depending on how the children uses the rooms.

KINFHT (Headteacher) from school 8 noted that;

"The school has no permanent building for classes which are spacious and conducive for learning, this has not enabled conducive learning for children which has really made it ineffective for transition of children from pre-school to grade one."

This gave an implication that classrooms in the preschool's centers are semi-permanent which has influenced the meeting expectation for transition from preschool to Grade one in Elgeyo Marakwet county, Kenya. This study findings agreed with Alimi (2012) who noted that classrooms in a school system are important because it protects children and teachers' wellbeing such as comfort, safety and performance while at school. According to Vandenbroeck and Lenaerts (2018), development of ECE facilities for young children in Europe promote sustainable and inclusive growth in children which resulted to high participation rates in ECE institutions. In addition, Barret et al (2018) noted that school physical facilities where children have rotation use of classes such as science laboratories, art workshops, library, and sports fields enhances participation rates. Hence, Physical Facilities alleviates overcrowding situations in some schools due to the intensive use of classes.

Also, $20(8.7 \%)$ of the respondents strongly agreed, $37(16.3 \%)$ agreed, $13(5.8 \%)$ were undecided, $67(29.8 \%)$ disagreed and $89(39.4 \%)$ strongly disagreed with the statement that some schools use mud houses as classes thatched with grass. Further the study findings showed in terms of means and standard deviation that the respondents disagreed that some schools use mud houses as classes thatched with grass (Mean, $=2.26$, Standard Deviation=1.356). The study results concur with Higgins (2017) who observed that in South America (Latin America) established that unavailability of physical facilities conducive for learning show lower test scores and high-grade repetition disrupting effective transition.

KINFPT (preschool teacher) from school 3 revealed that:

"With the coming up of devolution and county government taking up pre schools classes construction and payment of the pre schools teachers most of the pre schools structures have been upgraded to permanent buildings."

This gave and implication that modern classrooms are fast replacing grass-thatch mud houses or trees for classrooms after devolution and county government taking up pre schools activities. The study results concurred with Barret, Treves, Shmis, Ambasz and Ustinova (2018) who argued that unequal distribution of educational physical facilities conversely can create frustration and resentment which can result to low participation rates in schools. Barret, Treves, Shmis, Ambasz and Ustinova (2018) advocated schools to have adequate ECE facilities which can increase participation rates.

Further, 31(13.5\%) of the respondents strongly agreed, 22(9.6\%) agreed, 9(3.8\%) were undecided, $20(8.7 \%)$ disagreed and $146(4.4 \%)$ strongly disagreed with the statement that modern built latrines and toilets have been constructed in the school. Further the study 
findings showed in terms of means and standard deviation that Modern built latrines \& toilets have been constructed in the schools (Mean, $=2.02$, Standard Deviation=1.132).

KINFPT (preschool teacher) from school 14 elaborated that:

"Despite the fact that the schools have been upgraded majority of the schools hasn't reached a level of building Modern built latrines \& toilets."

This revealed that constructing a modern toilet is almost never a priority for many schools. Non modern toilets can become an illusion after heavy floods can caused the latrines at the pre schools centers to collapse. This can force the learners to endure the inconvenience and discomfort of sharing toilets. With one toilet to be used waiting queues also became longer as all children in the school had to rely on the remaining toilets. As such, the children would have ended up wasting valuable time that would have been used for studying or class attendance.

The study results concurred with O'Reilly (2016) who noted that the schools may have toilets, but are partially covered such that they expose the girls to the passers-by. Poor toilet and sanitation facilities for girls, is a major contributory factor in encouraging absenteeism among girls. Lack of privacy in the few available toilets and subsequent harassment of girls by boys led to girls abandoning school.

Furthermore, $41(18.3 \%)$ of the respondents strongly agreed, $46(20.2 \%)$ agreed, $11(4.8 \%)$ were undecided, 39(17.3\%) disagreed and 89(39.4\%) strongly disagreed with the statement that food store in the school is in good condition. Further the study findings showed in terms of means and standard deviation that the respondents were neutral with the statement that food store in the school is in good condition (Mean, $=2.61$, Standard Deviation=1.439). The results concede with (UN, 2015) who asserts that the importance of Pre-School development is not fast setting the foundation for cognitive, social, emotional, physical and language development of learners, but often is crucial in terms of pinpointing impediments of quality learning. The availability of enjoyable, safe and nutritious food, supported by a healthy food environment is fundamental to foster better diets in schools. Food environment shape how accessible, affordable, desirable and convenient specific foods are. A healthy school food environment allows and encourages the school community (children, families, school staff) to make food choices that are consistent with better diets and improved wellbeing.

Another, $15(6.8 \%)$ of the respondents strongly agreed, $26(11.5 \%)$ agreed, $11(4.8 \%)$ were undecided, 39(17.3\%) disagreed and 135(59.6\%) strongly disagreed with the statement that the school has structured and spacious fields. Further the study findings showed in terms of means and standard deviation that the respondents were neutral with the statement that the school has structured and spacious fields (Mean, $=1.88$, Standard Deviation=1.316). The study findings concur with (Beakye \& Boaten, 2015) who asserts that the quality of Physical Facilities appears to have an indirect impact on learning and transition. Frimpong's (2019) study findings showed that classrooms were not spacious enough for children's free movement. Many schools operated in poor environmental conditions that included classrooms that were not suitable for ECE since they had no decorations to attract children's attention.

KINFPT (preschool teacher) from school 9 argued that:

"For preschool centers to attain quality education and transition, then accessibility to quality educational, physical facilities and good infrastructure are very essential. These quality facilities have been determined to be a significant determinant of the school learning environment." 
This was done by studying the availability of a spacious library, adequacy of classrooms to handle all the students, adequate toilets and latrines, enough dormitories and availability of a spacious playing ground. Various studies done on effect of school environment on academic performance attest to the fact that school environment that is not conducive for learning may lead to under performance (Chimombe, 2011). Provision of adequate learning facilities at all levels including equipment and human resources enhances the quality and relevance of imparted skills of learners (Lumuli, 2009). Learning involves interaction of students with the environment. Teaching and learning resources include classrooms, laboratories, libraries, playing fields, textbooks among others. Indeed, physical resources go a long way in creating conducive environment that promote effective teaching and learning. It is with this in mind that the Draft Report on Cost and Financing of Education in Kenya that (RoK, 1995) identifies textbook ratio and school facilities as some yard sticks to be used to gauge the quality of secondary school education.

The study findings further, $20(8.7 \%)$ of the respondents strongly agreed, $48(21.2 \%)$ agreed, $2(0.9 \%)$ were undecided, $85(37.5 \%)$ disagreed and $72(31.7 \%)$ strongly disagreed with the statement that in our school we have self-contained administration block and offices for teachers. Further the study findings showed in terms of means and standard deviation that the respondents disagreed with the statements that in our school we have self-contained administration block and offices for teachers (Mean=2.39, Standard Deviation=1.352). This implied that administrative building block does not have room for the head teacher, his deputy and staff members. The administration block can be a landmark to the school and the teachers would have room to plan their lessons, mark the papers and go about their duties. The study results concede with Henard and Roseveare (2012) who postulates that physical facilities, teaching and learning resources are fundamental to the process of implementation of anew Pre-School Curriculum for smooth transition.

The study findings also, $15(6.7 \%)$ of the respondents strongly agreed, $54(24 \%)$ agreed, $7(2.9 \%)$ were undecided, $70(30.8 \%)$ disagreed and $80(35.6 \%)$ strongly disagreed with the statement that computer labs available for digital learning in our school. Further the study findings showed in terms of means and standard deviation that subjects disagreed with the statements that computer labs available for digital learning in our school (Mean, $=2.35$, Standard Deviation=1.357). this implied that increasingly, all aspects of life are moving online. The Covid-19 pandemic accelerated the global movement towards digitization. However, digital growth is not taking place evenly. Many young people in rural communities and in vulnerable, underserved areas of Africa are being left behind in the drive towards digitization. This is due to the high cost of internet access, the lack of consistent electricity supply and a lack of infrastructure that would support digital learning.

In Kenya, the government in 2016 initiated the Digital Literacy Programmed, providing locallymade tablets and laptops to students in public schools to facilitate digital learning. The government also provided solar solutions for schools that were not connected to the national electricity grid and funding for digital literacy programmed in private schools. In practice, however, not every school in Kenya has equal access to this state funding. Where this is the case, parents of students often cannot afford to fund the construction and maintenance of computer labs in schools. Even where computers are available, little progress is made as teachers often do not have the training to use digital tools. Further, there is insufficient maintenance of the computers. The study results concur with Chekwesis (2015) who found out that physical facilities for learning and materials of ICT programmed are in state of 
despair, thus, has stagnated the implementation of education and effective transition of preschool levels to Grade one.

Another, $35(15.4 \%)$ of the respondents strongly agreed, $46(20.2 \%)$ agreed, $7(2.9 \%)$ were undecided, 98(43.2\%) disagreed and $41(18.3 \%)$ strongly disagreed with the statement that the school mostly have semi-permanent buildings for pre-school learners. Further the study findings showed in terms of means and standard deviation that the respondents disagreed with the statement that school mostly have Semi-permanent buildings for pre-school learners (Mean, $=2.73$, Standard Deviation=1.384).

This gave an implication that the space to learn is one of the most basic elements necessary to ensure access to education. Although school classrooms are the most common location in which structured learning takes place, education can (and does) take place in a variety of locations in permanent school facilities; in tents or temporary school structures; under plastic sheeting or trees; in places of worship; in people's homes, etc. Spaces for learning are essential and should be demarcated even at the earliest stage of the creation of a new settlement or camp the study results concur with (Wangare, 2013) who asserts that Physical facilities, teaching and learning resources are fundamental to the process of implementation of anew Pre-School Curriculum for smooth transition.

KINFPT (preschool teacher) from school 13 elaborated that:

"Our pre schools classes are permanent we give thanks to CDF and county government of Elgeyo Marakwet for working smart to ensure we have permanent structures which are conducive for learning and as really boosted transition of our children from preschool to grade one. However, some schools have not benefited from this project."

This gave an implication that despite the County government building some pre schools in some areas of the county children have to swift access to learning opportunities than to buildings and actual facilities. Although shelter of some kind is needed, the initial temptation to begin constructing new buildings as soon as possible should not override the more critical need to hire and train teachers and to begin classes in a temporary structure so that children can quickly engage in educational activities.

Finally, 57(25\%) of the respondents strongly agreed, 120(52.9\%) agreed, 9(3.8\%) were undecided, $17(7.7 \%)$ disagreed and $24(10.6 \%)$ strongly disagreed with the statement that in the school, pre-school learners learn in the open air due to shortage of classes. Further the study findings showed in terms of means and standard deviation that the respondents disagreed with the statement that in the school, pre-school learners learn in the open air due to shortage of classes (Mean, $=3.76$, Standard Deviation=1.302). Despite the outdoor school is a breather for both parents and children after months of a grinding lockdown to slow down Covid-19 infections. Some schools have been suffering from shoartage of classes. The study results concede with Palmore, Branch and Harris, (2016) observed that learners may have soil connected infections because of in availability of enough and age-related furniture for proper testing spaces.

\section{Coefficients of the Variables}

The results on the regression coefficients of the variables are as indicated in Table 2. 


\begin{tabular}{llllll}
\hline & $\begin{array}{l}\text { Unstandardized } \\
\text { Coefficients }\end{array}$ & $\begin{array}{l}\text { Standardized } \\
\text { Coefficients }\end{array}$ & $\mathbf{t}$ & Sig. \\
& B & Std. Error & Beta & & \\
\hline (Constant) & .162 & .362 & & 8.735 & .000 \\
Physical facilities & -.140 & .066 & -.191 & -2.119 & .037 \\
\hline
\end{tabular}

Regression of coefficients results in Table 2 shows that physical facilities have a negative and significant effect on meeting expectation for transition from preschool to Grade one in Elgeyo Marakwet county $\left(\beta_{1}=-0.140, p=0.037\right)$. The results implied that a unit decrease in physical facilities caused 0.140 units decreased in meeting expectation for transition from preschool to Grade one. The resulting regression model is as follows:

$Y=0.162-0.140 X_{1}$

\section{Conclusion and Recommendations Conclusions}

The study concluded that physical facilities a negative significant influence on meeting expectation for transition from preschool to Grade one. The classrooms in the preschools centers are semi-permanent which has influenced the meeting expectation for transition from preschool to Grade one in Elgeyo Marakwet county, Kenya. Physical facilities alleviate overcrowding situations in some schools due to the intensive use of classes. The construction of a modern toilet is almost never a priority for many schools. Non modern toilets can become an illusion after heavy floods can caused the latrines at the preschools centers to collapse. This can force the learners to endure the inconvenience and discomfort of sharing toilets. Despite the County government building some pre schools in some areas of the county children have to swift access to learning opportunities than to buildings and actual facilities.

\section{Recommendations}

The study recommends the county government and other pre schools centers stakeholders to ensure that they build and avail the physical facilities. This will reduce the negative influence on meeting expectation for transition from preschool to Grade one. Physical facilities will reduce overcrowding situations in schools. They need to construct modern toilet hence reducing inconvenience and discomfort of sharing toilets. The management of pre schools centers should aid the development of more infrastructure by mobilizing resources from CDF, fundraising and LATF.

\section{Refference}

Agbenyega and Klibhong. (2015). Acquiring Skills for The Future Education

Barrett, P., Davies, F., Zhang, Y., \& Barrett, L. (2017). The Holistic Impact of Classroom Spaces on Learning in Specific Subjects. Environment And Behavior, 49(4), 425-451.

Benner, A. D., Thornton, A., \& Crosnoe, R. (2017). Children's Exposure to Sustainability Practices During the Transition from Preschool into School and Their Learning and Socioemotional Development. Applied Developmental Science, 21(2), 121-134.

Garba-Jimba, A. F. (2018). Influence Of Pre-School Education and Parents Socioeconomic Status on The Academic Performance of Pupils in Moro Local Government Area, Kwara State (Doctoral Dissertation, Kwara State University (Nigeria)). 
Guardino, C., \& Fullerton, E. K. (2012). The Classroom Infrastructure and The Early Learner: Reducing Aggression During Transition Times. Journal of the American Academy of Special Education Professionals, 100, 116.

Guo, Y., Justice, L. M., Kaderavek, J. N., \& Mcginty, A. (2012). The Literacy Environment of Preschool Classrooms: Contributions to Children's Emergent Literacy Growth. Journal of Research in Reading, 35(3), 308-327.

Habermas, J. (2015). Between Facts and Norms: Contributions to A Discourse Theory of Law and Democracy. John Wiley \& Sons.

Hacieminoglu, E. (2016). Elementary School Students' Attitude Toward Science and Related Variables. International Journal of Environmental and Science Education, 11(2), 35-52.

Henard, F., \& Roseveare, D. (2012). Fostering Quality Teaching in Higher Education: Policies and Practices. An IMHE Guide for Higher Education Institutions, 3(4),7-11.

Herrington, S., \& Brussoni, M. (2015). Beyond Physical Activity: The Importance of Play and Nature-Based Play Spaces for Children's Health and Development. Current Obesity Reports, 4(4), 477-483.

Higgins, B. (2017). Regional Development Theories and Their Application. Routledge.

Jepleting. (2019). Pre-School Classrooms Not Meeting Adequacy for Learning; Boston University

Juma, Z. R. (2015). Exploring The Development of Biological Literacy in Tanzanian Junior Secondary School Students.

Krach, S. K., Mccreery, M. P., \& Rimel, H. (2017). Examining Teachers' Behavioral Management Charts: A Comparison of Class Dojo and Paper-Pencil Methods. Contemporary School Psychology, 21(3), 267-275.

Mabatuk. (2016). Learners Learn Outside Due to Less Classrooms; United Kingdom

Maniates, H. (2016). Transitional Kindergarten: An Opportunity to Explore the Intersection Between Early Childhood and Kindergarten Practice. Early Child Development and Care, 186(5), 750-763.

Nyamwange. (2012). Basic Education for All

Obiweluozor. (2017). Definition Of Pre-School Education

Okebukola. (2019). Quality Education as Key Factor; Rome

Ortega, F. B., Cadenas-Sánchez, C., Sánchez-Delgado, G., Mora-González, J., Martínez-Téllez, B., Artero, E. G., ... \& Ruiz, J. R. (2015). Systematic Review and Proposal of a Field-Based Physical Fitness-Test Battery in Preschool Children: The PREFIT Battery. Sports Medicine, 45(4), 533-555.

Palmore, E. B., Branch, L., \& Harris, D. (2016). Encyclopedia Of Ageism. Routledge.

Pellegrini, A., \& Blatchford, P. (2014). The Child at School. Routledge.

Rodríguez, A. M. L. (2015), Learning Environments Mediated by Childrens Narrative to Stimulate Transition from Preschool to Primary.

Salmi, S., \& Kumpulainen, K. (2019). Children's Experiencing of Their Transition from Preschool to First Grade: A Visual Narrative Study. Learning, Culture and Social Interaction, 20, 5867.

Shinali, M. C. (2020). Determinants Influencing Learners' Transition from Pre-Primary to Grade One in Primary Schools of Narok County.

Sitati. (2016). Important Facilities for Learning to Continue Well; Kenya: University of Nairobi Struthers, A. E. (2015). Human Rights Education: Educating About, Through and For Human Rights. The International Journal of Human Rights, 19(1), 53-73. 
INTERNATIONAL JOURNAL OF ACADEMIC RESEARCH IN BUSINESS AND SOCIAL SCIENCES

Vol. 12, No. 1, 2022, E-ISSN: 2222-6990 @ 2022 HRMARS

Winder, C., \& Corter, C. (2016). The Influence of Prior Experiences on Preschool Education Students' Anticipated Work with Families. Teaching And Teacher Education, 55, 133142. 